Print ISSN: 2288-4637 / Online ISSN 2288-4645

doi:10.13106/jafeb.2020.vol7.no12.377

\title{
Capital Buffer and Determinant Factors of Conventional Banks in Indonesia*
}

\author{
Anisa ANISA ${ }^{1}$, Sutrisno SUTRISNO ${ }^{2}$
}

Received: September 01, 2020 Revised: October 26, 2020 Accepted: November 05, 2020

\begin{abstract}
Banking is very regulated by the government and even has to follow regulations issued by the Basel Committee on Banking Supervision, which regulates banking in the world. According to Basel III, banks must provide capital reserves called capital buffers. The purpose of this study is to examine the factors that determine capital buffer. Factors thought to affect the capital buffer studied consisted of profitability (ROA), credit risk (NPL), liquidity risk (LDR), capital adequacy in the previous period (CARt-1), management risk (NIM), and ratio of operating risk (OER). The population in this study is conventional banks listed on the Indonesia Stock Exchange, as many as 42 banks, with a sample of 40 banks taken by purposive sampling method with an observation period of four years with quarterly data (2016-2019). To test the hypotheses, regression panel data is used. After being tested, it turns out that the fixed effect model is better than the common effect and random effect. The results of the study with fixed effect models show that ROA, NPL, and OER significantly and negatively affect capital buffer. $\mathrm{CAR}_{\mathrm{t}-1}$ has a positive and significant effect on capital buffer, while LDR and NIM do not affect capital buffer.
\end{abstract}

Keywords: Capital Buffer, Non-Performing Loan, Deposit Ratio, Net Interest Margin, Capital Adequacy Ratio

JEL Classification Code: G21, G24, G28

\section{Introduction}

Banking institutions are fundamental institutions for the operation of the economic system, especially because of their role as financial intermediaries (Distinguin et al., 2013). Banking institutions play a role in mobilizing funds from the

\footnotetext{
*Acknowledgments:

This paper is a research output funded by the Ministry of Education and Culture of the Republic of Indonesia in a postgraduate grant scheme No. 081/SP2H/LT/DRPM/2020. We would like to thank you very much for giving high appreciation for the grants given to this research.

${ }^{1}$ First Author. Graduate Student, Department of Management, Faculty of Business and Economics, Universitas Islam Indonesia, Yogyakarta, Indonesia.

${ }^{2}$ Corresponding Author. Associate Professor, Department of Management, Faculty of Business and Economics, Universitas Islam Indonesia, Yogyakarta, Indonesia [Postal Address: Kampus Condong Catur, Depok, Sleman, Yogyakarta, 55283, Indonesia] Email: sutrisno@uii.ac.id

(c) Copyright: The Author(s)

This is an Open Access article distributed under the terms of the Creative Commons Attribution Non-Commercial License (https://creativecommons.org/licenses/by-nc/4.0/) which permits unrestricted non-commercial use, distribution, and reproduction in any medium, provided the original work is properly cited.
}

public, with excess funds or surplus units to be distributed to people who need funds or a deficit of funds. Eliskovski (2014) also agrees that banks occupy an important position in the modern financial sector. Most of the sources of bank funds come from the public, so that in operating the bank must comply with regulations, supervision and control by the government through the financial services authority (OJK). One of the most important elements that must be regulated by the government is bank capital, because capital is a key element in maintaining their solvency

To support a strong, healthy and stable financial system, financial regulators determine regulations related to the adequacy of bank capital. As stated by Masood et al. (2013), the capital adequacy regulation was adopted from the Basel Committee on Banking Supervision, namely, BASEL I, II and III. In the Basel agreement, a minimum capital adequacy ratio (CAR) is set at $8 \%$. BASEL III also requires banking institutions to have a capital buffer to deal with the various risks it faces (Brasliņ̌̌ \& Arefjevs, 2014).

Until 2019, almost all European countries have set a minimum capitalization of $10.5 \%$. This capital includes a capital buffer, meaning that with a capital adequacy ratio (CAR) of $8 \%$, there is a reserve of $2.5 \%$ as a capital buffer 
(Distinguin et al., 2013). There are even those who are more careful, such as in Switzerland, where the capital that must be provided is $19 \%$, whereas $9 \%$ is placed in government bonds, which are considered the safest

Deputy Commissioner for Banking Supervision of the Financial Services Authority (OJK), Irwan Lubis, said that banks in Indonesia will gradually build additional capital in the form of capital conservation buffers, countercyclical buffers, and capital surcharges for banks that are included in the list of domestic systemically important banks (DSIB). The amount of capital conservation buffer is set at $2.5 \%$ of risk weighted assets and the countercyclical buffer is in the range of $0 \%-2.5 \%$ of risk weighted assets. Specifically for DSIB, the regulator stipulates an additional capital surcharge of $1 \%-2.5 \%$ from the equity (Raharjo et al., 2014)

Capital buffer is defined as the excess difference between the capital adequacy ratio (CAR) owned by banks and the minimum bank capital requirements imposed by regulators (Brasliņ̌ \& Arefjevs, 2014). Capital buffer can be a protector that can absorb various risks that may arise (Wong et al., 2008). In Bank Indonesia's explanation, capital buffer is additional capital that functions as a buffer to anticipate losses in the event of excessive credit growth and / or bank credit, which has the potential to disrupt financial system stability.

Capital buffer is very important for banks, which face various risks and economic shocks that occur at any time. The higher the capital buffer, the stronger the bank, and it is hoped that the public will have more trust in the bank, which in the end they will take advantage of the bank's services. There are several factors that affect the capital buffer, including the level of profitability, credit risk, previous CAR, bank liquidity requirements, and bank efficiency as measured by OER (Maurin \& Toivanen, 2012).

Bank profitability affects the capital buffer because the higher the bank's profit, the more it provides an opportunity to increase the capital buffer, because part of the profit earned will be set aside as retained earnings and will be accumulated in its own capital, thereby increasing the capital buffer. Like the findings of Belém and Gartner (2016) in Brazil and Haryanto and Indonesia (2015) in Indonesia, profitability affects the capital buffer. However, the findings of Noreen et al. (2016) found a significant and negative effect between profitability as measured by ROA on capital buffer.

Non-performing loans (NPLs) reduce profits because they will become costs and reduce profits. The higher the NPL, the more likely it will reduce profits and even cause losses. This loss must be covered with capital, thereby reducing bank capital and having an impact on reducing the capital buffer. The results of research by $\mathrm{He}$ and $\mathrm{Fu}$ (2009) found that in China NPL has a negative effect on capital buffer, while Tamimi and Obeidat (2013) in Jordan found NPL does not affect capital buffer. On the other hand, Sutrisno (2018) found a positive influence between credit risk as measured by NPL and capital buffer.

Islamic bank liquidity as measured by the loan-to-deposit ratio (LDR) shows the higher the LDR, the higher the credit given. With the higher the LDR, the higher the bank's income, which in turn will increase the bank's capital. The results of research by Sutrisno (2018) show that in China LDR has a positive effect on capital buffer. Likewise, Belém and Gartner (2016) also found a significant effect between LDR and capital buffer. Meanwhile, Mili et al. (2017) and Haryanto (2015) found an insignificant effect on LDR and capital buffer.

The capital adequacy ratio (CAR) in the previous period also triggered the high and low capital buffer. If the CAR in the previous period was high, the capital buffer it had could be maintained high in order to maintain its performance in accordance with government regulations. However, if the CAR in the previous period was low, the capital buffer would also be low, however, banks can try to increase their capital buffer. The results of research by Jiang et al. (2020) in America and Noreen et al. (2016) in Indonesia found that the effect of the previous CAR with a capital buffer had a positive effect. Meanwhile, the research results of Belém and Gartner (2016) found a negative effect between $\mathrm{CAR}_{\mathrm{t}-1}$ on capital buffer. Meanwhile, Suputra (2013) found insignificant effects.

Bank management must be able to control Net Interest Margin (NIM), because NIM is an indicator used to determine the ability of bank management in managing productive assets so that it can generate net income (Widarjono et al., 2020). The greater the NIM ratio will affect the increase in bank income obtained from productive assets managed by the bank properly. The higher the NIM will be able to increase the capital buffer, because it shows the bank's profits are getting bigger so that it can increase the capital buffer. (Mili et al., 2017) found a positive influence between NIM and CAR, while Suputra (2013) found that NIM had no effect on CAR.

Bank management is also required to work efficiently, namely, being able to reduce operational costs to a minimum. Bank efficiency is measured by the ratio between operating costs and operating income (OER). This ratio is to measure the level of efficiency and the ability of the bank to carry out its operational activities. OER, also often called the efficiency ratio, is used to measure the ability of bank management to control operating costs against operating income. The smaller the ratio, the more efficient the operational costs incurred by the bank concerned. It is hoped that low OER will be able to generate a higher level of profit, so that it can be used to increase the bank's capital buffer. However, Haryanto's (2015) research in Indonesia and Tamimi and Obeidat (2013) actually found an insignificant effect on capital adequacy. 


\section{Literature Review and Hypothesis Development}

\subsection{Profitability Against Capital Buffer}

The purpose of the company is to make a profit and some of the profits are used to pay dividends and partially as retained earnings. To measure a company's ability to generate profits, you can use the return-on-assets ratio (ROA). Return-on-assets represents all assets owned by a bank and its ability to generate profits over a certain period of time; in other words, it explains the extent to which the bank has successfully invested its assets and produced efficiency in directing it toward a profitable investment opportunity (Ghosh, 2017). The higher the profit, the greater the retained profit. Retained earnings will increase their own capital, so that the higher the retained profit will increase the amount of own capital. Thus, the high profit will increase the capital buffer. In Brazil, the results of research between profitability and capital buffer shows a positive and significant effect (Belém \& Gartner, 2016). Haryanto (2015) and Masood et al. (2013), who conducted a study in Indonesia, also found the same thing. $\boldsymbol{H}_{1}$ :
buffer

$\boldsymbol{H}_{I}:$ Profitability (ROA) has a positive effect on capital

\subsection{The Effect of Non-Performing Loans on Capital Buffer}

The indicator used to determine the credit risk of a bank is the non-performing loan (NPL). Jiang et al. (2020) say that non-performing loans are a comparison between nonperforming loans to total loans. Non-performing loans are a reflection of credit risk, namely, the risk due to failure of debtors and/or other parties in fulfilling obligations to banks. High credit risk can hinder bank operations and growth, this happens because bad credit or high credit defaults will require larger funds to finance bank operations. High credit risk means that the capital buffer that the bank must provide is getting bigger. A large non-performing loan indicates a bad bank performance because the possibility of a bank experiencing greater losses. Banks with high non-performing loans tend to be inefficient. High non-performing loans indicate bank failure in operations, because non-performing loans will reduce profits and even cause losses. If the bank experiences a loss, the loss can eat away at its own capital, which results in a decreased capital ratio and ultimately a lower capital buffer. If a bank with a high NPL and experiences a loss, the loss will reduce its own capital. Jiang et al. (2020) in China, found that in China NPL has a negative effect on capital buffers. Meanwhile Tamimi and Obeidat (2013) found that NPL had no effect on capital buffer.
$\boldsymbol{H}_{2}:$ Non-performing loans (NPL) have a negative effect on the capital buffer

\subsection{Effect of Loan-to-Deposit Ratio on Capital Buffer}

Loan-to-deposit ratio is a ratio used to measure bank liquidity. Bank liquidity is a bank's ability to meet customer needs in the form of cash or credit. Loan-to-deposit ratio, the ratio between loans and third party funds (Dao \& Nguyen, 2020). The higher the loan-to-deposit ratio, the higher the credit given. The higher the credit provided by the bank, the bank must be able to provide a higher source of funds. On the contrary, the smaller the loan-to-deposit ratio, the higher the third party funds that are not used for credit placement. So that, in this case, many funds are idle or not used. The main income of a bank comes from credit, so the higher the credit, the higher the income, which in turn will increase profits. So that the higher the loan-to-deposit ratio, the higher the capital buffer. Belém and Gartner (2016) and Haryanto (2015) found that liquidity risk as measured by the loan-to-deposit ratio has a positive effect on capital buffer.

$\boldsymbol{H}_{3}$ : Loan-to-deposit ratio (LDR) has a positive effect on capital buffer

\subsection{The Influence of Capital Adequacy Ratio on Capital Buffer}

Capital adequacy ratio (CAR) is a ratio used to measure the capital adequacy capacity of a bank (Tangngisalu, et al., 2020). Capital adequacy ratio is a ratio that shows the ability of bank capital to bear the risk of financing failure that may occur, a high capital adequacy ratio, indicating that banks have sufficient and healthy funds and vice versa. Low capital adequacy ratio, the possibility that the risk of failure in bank financing will be higher (Dao \& Nguyen, 2020). Based on Bank Indonesia Regulation Number 15/12/PBI/2013, banks are required to provide a minimum capital of $8 \%$ of risk weighted assets. Capital buffer is reserve capital to anticipate a lack of capital adequacy. To find the capital buffer is to subtract the CAR available from the minimum CAR. Thus, if the capital adequacy ratio is high, the capital buffer will be high, conversely, if the capital adequacy ratio in the previous period was low, the capital buffer will be low. Noreen et al. (2016) found a significant effect between CARt-1 and capital buffer. Likewise, Masood et al. (2013) who conducted a study in Pakistan found a significant effect between CAR and capital buffer.

$\boldsymbol{H}_{4}:$ Capital adequacy ratio (CARt-1) has a positive effect on capital buffer 


\subsection{The Effect of Net Interest Margin on Capital Buffer}

To measure the ability of bank management to generate net interest income, namely, the net interest margin ratio (NIM). Net interest margin is a financial reflection of a bank and is defined as net interest income divided by the bank's average earning assets. Net interest income is bank interest income minus interest costs (Raharjo et al., 2014). The ability of bank management to manage its earning assets to earn net interest as measured by the net interest margin ratio. Net interest income is obtained from interest income less interest expenses (Eliskovski, 2014). The quality of bank management is proxied by the net interest margin ratio, a variable that affects the size of the capital buffer. NIM is used to measure management's ability to generate net interest income divided by productive assets. Net interest margin reflects the cost of financial intermediation, so the higher the net interest margin the higher the available capital buffer. Mili et al. (2017) and Raharjo et al. (2014) found that net interest margin has a positive effect on capital adequacy.

$\boldsymbol{H}_{5}:$ Net interest margin (NIM) has a positive effect on capital buffer

\subsection{The Effect of Operating Costs on Operating Income on Capital Buffer}

One of the important aspects in banking is efficiency in order to increase the level of bank profits (Banna et al., 2017). In the very tight competition in the banking industry, the advantage of efficiency is highly recommended. Efficiency is measured by operating costs to operating income (OER), meaning that the higher this ratio, the more inefficient bank operations are. OER is a comparison between operating costs and operating income. To measure whether the bank management has used all production factors effectively and efficiently. Operating costs to operating income ratio (OER) are high indicating the large amount of operating costs, so they require more funds (Haryanto, 2015). The more efficient the bank will be able to increase profits, which in turn can increase the capital buffer. As disclosed by (Raharjo et al., 2014) who found a positive influence between OER and capital buffer.

$\mathrm{H}_{6}:$ Operating costs on operating income have a positive effect on capital buffer

\section{Research Method and Materials}

\subsection{Population and Samples}

The population in this study was 42 conventional banks operating in Indonesia and listed on the Indonesia Stock Exchange. The sampling method used was purposive sampling method, namely, taking samples with special characteristics or certain criteria to answer research problems, and reaching out as many as 40 banks. The fundraising period was four years with quarterly data, in order to obtain 640 research data.

\subsection{Research Variables}

In this study, there is one dependent variable, namely, the capital buffer (BUFF) and six independent variables, namely, profitability (ROA), non-performing loans (NPL), loan-to-deposit ratio (LDR), the previous capital adequacy ratio (CARt-1), net interest margin (NIM), and the ratio of operating expenses to operating income (OER). Here are the measurements of the variables:

Table 1: variable Measurement

\begin{tabular}{|l|c|l|}
\hline Variable & Notation & \multicolumn{1}{|l|}{ Measurement } \\
\hline Dependent. Variable: & BUFF & CAR available - CAR minimum \\
\hline Capital Buffer & ROA & EAT/Total Assets \\
\hline Independent Variable: & NPL & Non perform Loan/Total Loan \\
\hline Profitability & LDR & Total Loan/Third Party Funds \\
\hline Non Performing Loan & CAR & Equity ${ }_{\mathrm{t}-1} /$ Assets bared Risk $_{\mathrm{t}-1}$ \\
\hline Loan to Deposit Ratio & NIM & Interest Income/Productive Assets \\
\hline Capital Adequacy Ratio previous period & OER & Operating Expenses/Operating Income \\
\hline Net Interest Margin &
\end{tabular}




\subsection{Data Analysis}

This study measures the factors that influence the capital buffer in conventional banks in Indonesia. Because the data is panel data where there are 40 banks over a period of four years on a quarterly basis. The panel regression model is as follows:

$$
\begin{aligned}
\mathrm{BUFF}_{\mathrm{it}}= & \beta_{0}+\beta_{1} \mathrm{ROA}_{\mathrm{it}}+\beta_{2} \mathrm{NPL}_{\mathrm{it}}+\beta_{3} \mathrm{LDR}_{\mathrm{it}}+\beta_{4} \mathrm{CAR}_{\mathrm{t}-1 \mathrm{it}} \\
& +\beta_{5} \mathrm{NIM}_{\mathrm{it}}+\beta_{6} \mathrm{OER}_{\mathrm{it}}+\varepsilon_{\mathrm{it}}
\end{aligned}
$$

\section{Results and Discussion}

\subsection{Results}

Table 2 exhibits descriptive statistics for all variables being studied. Table 2 shows that the capital buffer has a minimum value of $0.01 \%$, which means that there are banks operating below the minimum requirements. However, in general, the capital buffer is very good because the average value of $14.09 \%$ is still far above the requirement. In terms of profitability, the bank's performance has shown poor performance, because the average price is $1.01 \%$, and some banks even experience losses until the minimum ROA is minus $20.19 \%$. Non-performing loans (NPLs) are generally very good, below the $5 \%$ maximum requirement, because they have an average value of $2.05 \%$, with a minimum value of $0.00 \%$, but there are banks that still have very high NPLs with a maximum value of $10.93 \%$. The credit given, which is indicated by the LDR, is very good because the average is $85.75 \%$ is still in the ideal range, but there are banks that provide too large credit with a maximum value of $171.32 \%$; however, there are banks that are not able to channel credit properly so that the minimum value is only $14.60 \%$.

The previous capital adequacy ratio (CARt-1) showed a minimum value of $8.01 \%$, meaning that it has a mediocre CAR because the minimum CAR is $8 \%$, but overall bank capital is very good because the average value is $20.86 \%$; there are even banks that have CAR up to $76.42 \%$. The net interest margin (NIM) has an average value of $4.78 \%$ with a minimum value of $0.00 \%$ and a maximum value of $11.97 \%$. Meanwhile, OER, which is an indicator of operational efficiency, has an average value of $90.95 \%$, meaning that it is still efficient, especially since there are banks that have a minimum OER of $58.24 \%$. However, there are banks that operate with very high operating expenses of $432.73 \%$ as shown in the minimum OER value.

To test the hypotheses, panel data regression analysis is used, therefore there are steps in determining the best model between the common effect (pool), fixed effect or random effect model. The following are the results of calculations using the e-Views of each model.

The first step in panel data regression is to choose between common effect and fixed effect models. By using the Chow test, the results of the fixed effect model are better than the common effect. The second step is to choose between the common effect model and the random effect with the Lagrange Multiplier test, which results in a better random effect model. Furthermore, the third step is choosing the best model between the fixed effect and the random effect using the Hausman test. The Hausman test results show that the fixed effect model is better than the random effect model. Thus, what will be used for further discussion is the results of hypothesis testing based on the fixed effect model.

Table 3 shows that the profitability variable has a significant but negative effect on capital buffer with a significance level of $1 \%$, meaning that the hypothesis that states that profitability has a positive effect on capital buffer is rejected. The non-performing loan (NPL) variable has a significant and negative effect on the capital buffer with a significance level of $1 \%$, meaning that the hypothesis is proven. Meanwhile, the loan-to-deposit ratio (LDR) has no effect on the capital buffer.

Table 2: Descriptive Statistics

\begin{tabular}{|l|c|c|c|c|c|}
\hline & N & Minimum & Maximum & Mean & Std. Deviation \\
\hline BUFF & 640 & 0.01 & 140.28 & 14.0914 & 9.8844 \\
\hline ROA & 640 & -20.19 & 4.68 & 1.0068 & 2.3688 \\
\hline NPL & 640 & 0 & 10.93 & 2.0452 & 1.3379 \\
\hline LDR & 640 & 9.49 & 171.32 & 85.754 & 14.6014 \\
\hline CAR ${ }_{\mathrm{t}-1}$ & 640 & 8.01 & 76.42 & 20.8606 & 7.5579 \\
\hline NIM & 640 & 0 & 11.97 & 4.7761 & 1.6759 \\
\hline OER & 640 & 58.24 & 432.73 & 90.9497 & 26.6616 \\
\hline Valid N (listwise) & 640 & & & \\
\hline Note: The number of observations is 640 consisting 40 conventional banks and covering. \\
\hline 2016 Q1 - 2019Q4
\end{tabular}


Table 3: Determinant of Capital Buffer (BUFF)

\begin{tabular}{|c|c|c|c|}
\hline Variable & Pooled & Fixed & Random \\
\hline \multirow[t]{2}{*}{ C } & 24.0731 & 46.7499 & 25.0417 \\
\hline & 5.5537 & 6.4607 & 4.9744 \\
\hline \multirow[t]{2}{*}{ ROA } & -3.3908 & -3.8219 & -3.4258 \\
\hline & $0.617078^{* * *}$ & $0.603672^{* * *}$ & $0.603672^{* * *}$ \\
\hline \multirow[t]{2}{*}{ NPL } & -1.0349 & -2.2082 & -1.0948 \\
\hline & $0.271^{* * *}$ & $0.603672^{* * *}$ & $0.245437^{* * *}$ \\
\hline \multirow[t]{2}{*}{ LDR } & -0.0387 & -0.0146 & -0.0395 \\
\hline & $0.021407^{*}$ & 0.0322 & $0.019523^{* *}$ \\
\hline \multirow[t]{2}{*}{$\mathrm{CAR}_{\mathrm{t}-1}$} & 0.7163 & 0.1609 & 0.6946 \\
\hline & $0.041932^{* * *}$ & $0.05855^{* * *}$ & $0.03813^{* * *}$ \\
\hline \multirow[t]{2}{*}{ NIM } & 0.882 & -0.0898 & 0.879 \\
\hline & $0.232503^{* * *}$ & 0.4484 & $0.212204^{* * *}$ \\
\hline \multirow[t]{2}{*}{ OER } & -0.2231 & -0.2856 & -0.2261 \\
\hline & $0.051991^{* * *}$ & $0.049686^{* * *}$ & $0.046286^{* * *}$ \\
\hline R-Square & 0.39438 & 0.55504 & 0.373338 \\
\hline $\mathrm{N}$ & 840 & 840 & 840 \\
\hline F-test & 0.000 & 0.000 & 0.000 \\
\hline Chi test & & & 0.000 \\
\hline \multicolumn{4}{|c|}{ Note: ${ }^{* * *},{ }^{* *},{ }^{*}$ denote significant $1 \%, 5 \%$, and $10 \%$ respectively. } \\
\hline \multicolumn{4}{|c|}{$\mathrm{N}$ is the number of observation } \\
\hline
\end{tabular}

The previous period's capital adequacy ratio $\left(\mathrm{CAR}_{\mathrm{t}-1}\right)$ had a positive and significant effect with a significance level of $1 \%$, so the hypothesis that states that $\mathrm{CAR}_{\mathrm{t}-1}$ had a positive effect on capital buffer is accepted. Net interest margin (NIM) has no effect on the capital buffer. Meanwhile, OER has a significant effect, but has a negative effect on the capital buffer, meaning that the hypothesis is accepted

\subsection{Discussion}

Profitability is an indicator of management's performance in managing the company. If the profitability is high, the bank's performance is very good and the company is able to set aside a portion of the profit to be reinvested. The retained earnings will increase capital adequacy, which in turn will increase the capital buffer. However, in reality, profitability has a negative effect, meaning that an increase in profitability will reduce the capital buffer. This is probably due to the profit rate (ROA) of conventional banks on average very small, namely, only $1 \%$, and some banks even experience losses of up to $20 \%$. These results confirm the results of research by Masood et al. (2013); Noreen et al., (2016); and Tamimi and Obeidat (2013) who found a significant and negative effect between profitability as measured by ROA on bank capital ratios. Likewise, the research results by Eliskovski (2014) also found a significant and negative effect between profitability and the capital adequacy ratio. On the other hand, research conducted by Belém and Gartner (2016) in Brazil and Haryanto (2015) in Indonesia found that profitability has an effect on capital buffers.

Credit risk as measured by non-performing loans (NPL) shows that the higher the loss will be to the bank. Therefore, every bank will try to reduce the NPL as low as possible so that the company does not suffer losses. NPL has a significant and negative effect on the capital buffer, meaning that the higher the NPL, the lower the capital buffer. This is because NPLs have the potential to reduce profits so that they can reduce bank capital. The bank capital declines, the more it reduces the ability of banks to provide capital buffers. Sutrisno (2018) found that, in Islamic banks in Indonesia, credit risk also reduces the capital buffer. Likewise, He and $\mathrm{Fu}$ (2009) found that in China NPLs have a negative effect on capital buffers. Meanwhile, Raharjo et al. (2014) found a positive influence between credit risk as measured by NPL and capital buffer. Meanwhile, Tamimi and Obeidat (2013) in Jordan found that NPL did not affect the capital buffer.

Loan-to-deposit ratio (LDR) shows a bank's ability to extend credit, the higher the LDR, the higher the credit given. Credit is the main income for banks, so if the LDR is high it indicates that the credit given is large. Large credit, if managed properly, can generate high interest income, and the higher the interest, the higher the profit. Thus, the LDR is able to contribute to increasing the buffer capital. However, in reality, the results of the research resulted in LDR not having a significant effect on capital buffer. This is possible because it turns out that LDR is not able to increase profitability (Masood et al., 2013), even the results of this study have a negative effect on the capital buffer. This finding supports the findings by Sutrisno (2018) and Haryanto (2015), who found an insignificant effect of LDR with capital buffer. While different results were found by Eliskovski (2014) and Belém and Gartner (2016) who showed a significant effect between LDR and capital buffer.

Bank management has a strong interest in the capital adequacy ratio (CAR) because CAR is one aspect in assessing the health of a bank. Banks must maintain a minimum CAR of $8 \%$. The higher the CAR, the higher the capital buffer because the capital buffer is calculated by means of the available CAR minus $2.5 \%$. It is possible that the previous high CAR for the period will be maintained thereby increasing the capital buffer. The results showed that the previous CAR had a psychological and significant effect, so that it was in accordance with the theory and hypothesis. These results are consistent with the findings by Belém and Gartner (2016) who found the effect of previous capital buffers. Likewise, Wong et al. (2008) in America 
and Sutrisno (2018) in Indonesia also found the effect of previous CAR with a capital buffer. In contrast, Hewaidy and Alyousef (2018) found insignificant effects.

Bank management must be able to control net interest margin (NIM), because NIM is an indicator used to determine the ability of bank management in terms of managing productive assets so that it can generate net income. The greater the NIM ratio will affect the increase in bank income obtained from productive assets managed by the bank properly. The higher the NIM, the greater the capital buffer, because it indicates that the bank's profits are getting bigger so that it can increase the capital buffer. However, the research result shows that NIM has no effect on the capital buffer. This is possible in line with the profitability hypothesis test having a negative effect, and the LDR hypothesis testing has no effect on the capital buffer. LDR shows the amount of credit given and the credit given will affect interest income. If the LDR has no effect on the capital buffer, then NIM should not be affected because NIM is the ratio of interest income to earning assets. These results confirm the research by Noreen et al. (2016) that found a positive effect between NIM and CAR, while Raharjo et al. (2014) actually found NIM had no effect on CAR.

Hypothesis test results show OER has a significant and negative effect on capital buffer. This result is in accordance with the hypothesis that BOP has a negative effect on capital buffer. Bank management is required to work efficiently, namely, being able to reduce operational costs to a minimum. Bank efficiency is measured by the ratio between operating costs and operating income (OER). This ratio is to measure the level of efficiency and the ability of the bank to carry out its operational activities. OER is also often called the efficiency ratio, which is used to measure the ability of bank management to control operating costs against operating income. The smaller the ratio, the more efficient the operational costs incurred by the bank concerned. It is hoped that low OER will be able to generate a higher level of profit, so that it can be used to increase the bank's capital buffer. However, Haryanto (2015) in Indonesia and Tamimi and Obeidat (2013) actually found an insignificant effect on capital adequacy.

\section{Conclusions}

Based on the results of research and discussion, it can be concluded that there are three unsupported hypotheses: first, profitability as measured by ROA has a significant effect, but has a negative effect on capital buffer. Second, liquidity risks as measured by the loan-to-deposit ratio (LDR) do not have a significant effect on the capital buffer. Third, management risks as measured by the net interest margin (NIM) also have no significant effect on the capital buffer. Meanwhile, there are two supported hypotheses: first, credit risk as measured by non-performing loans (NPL) has a significant, but negative effect on the capital buffer; second, CAR has a significant and positive effect on the capital buffer

The researcher hopes that the results of the research can be used by conventional bank management in Indonesia as material for consideration in managing banks. The variables related to profit need attention because it has an impact on the fulfillment of the capital buffer, which in turn will also have an impact on the fulfillment of the capital adequacy ratio (CAR).

The results of this study are also expected to be used by researchers as additional references, especially those related to capital buffers. This research still has many weaknesses, so it is hoped that the topic can be further investigated, for example, by adding samples or variables to complement this research.

\section{References}

Banna, H., Ahmad, R., \& Koh, E. H. Y. (2017). Determinants of Commercial Banks' Efficiency in Bangladesh: Does Crisis Matter? Journal of Asian Finance, Economics and Business, 4(3), 19-26. https://doi.org/10.13106/jafeb.2017.vol4.no3.19

Belém, V. C., \& Gartner, I. R. (2016). Análise Empírica dos Buffers de Capital dos Bancos Brasileiros no Período de 2001 a 2011. Revista Contabilidade e Financas, 27(70), 113-124. https://doi. org/10.1590/1808-057x201612300

Brasliņš, G.., \& Arefjevs, I. (2014). Basel III : countercyclical capital buffer proposal- the case of Baltics. Procedia - Social and Behavioral Sciences, 110, 986-996. https://doi.org/10.1016/j. sbspro.2013.12.945

Dao, B. T. T., \& Nguyen, K. A. (2020). Bank capital adequacy ratio and bank performance in Vietnam: A simultaneous equations framework. Journal of Asian Finance, Economics and Business, 7(6), 39-46. https://doi.org/10.13106/jafeb.2020.vol7.no6.039

Distinguin, I., Roulet, C., \& Tarazi, A. (2013). Bank regulatory capital and liquidity: Evidence from US and European publicly traded banks. Journal of Banking and Finance, 37(9), 32953317. https://doi.org/10.1016/j.jbankfin.2013.04.027

Eliskovski, M. (2014). The Determinants of Capital Buffer in The Macedonian Banking Sector. Journal of Contemporary Economic and Business Issues, 1(2), 19-33.

Ghosh, S. (2017). Capital buffers in Middle East and North Africa (MENA) banks : is market discipline important?, (pillar 2). https://doi.org/10.1108/IMEFM-08-2016-0101

Haryanto, S. (2015). Determinant Capital Buffer: Empirical Review. Modernisasi, 11(2), 108-123.

He, C., \& Fu, R. (2009). An empirical study on the locational choices of foreign banks in China. Dili Xuebao/Acta Geographica Sinica, 64(6), 701-712. https://doi.org/10.12691/jfe-4-3-4

Hewaidy, A. M., \& Alyousef, H. Y. (2018). Bank-Specific and Macroeconomic Determinants of Capital Adequacy Ratio: 
Evidence from Kuwaiti Banks. European Journal of Economics, Finance and Administrative Sciences, 99, 5-20.

Jiang, H., Zhang, J., \& Sun, C. (2020). China Economic Review How does capital buffer affect bank risk-taking ? New evidence from China using quantile regression. China Economic Review, 60(May 2019), 101300. https://doi.org/10.1016/j. chieco.2019.04.008

Masood, Usman, \& Ansari, S. (2013). Determinants of Capital Adequacy Ratio. Pakistani Banking Sector. International Journal of Economics, Commerce, and Management, IV(7), 149-162.

Maurin, L., \& Toivanen, M. (2012). Risk, capital buffer and bank lending: a granular approach to the adjustment of euro area banks. ECB Working Paper 1499.

Mili, M., Sahut, J. M., Trimeche, H., \& Teulon, F. (2017). Determinants of the capital adequacy ratio of foreign banks' subsidiaries: The role of interbank market and regulation. Research in International Business and Finance, 42(February 2020), 442-453. https://doi.org/10.1016/j.ribaf.2016.02.002

Noreen, U., Alamdar, F., \& Tariq, T. (2016). Capital buffers and bank risk: Empirical study of adjustment of Pakistani banks. International Journal of Economics and Financial Issues, 6(4), 1798-1806.

Raharjo, P. G., Hakim, D. B., Manurung, A. H., \& Maulana, T. N. A. (2014). Determinant of Capital Ratio: a Panel Data Analysis on State-Owned Banks in Indonesia. Buletin Ekonomi Moneter Dan Perbankan, 16(4), 369-386. https://doi.org/10.21098/ bemp.v16i4.451
Suputra, O. (2013). Determinants Of European Banks' Capital Adequacy. Journal of Chemical Information and Modeling, 53(9), 1689-1699. https://doi.org/10.1017/ CBO9781107415324.004

Sutrisno, M. (2018). Factors determinant of bank capital buffer: empirical study on Islamic rural banking in Indonesia, 186(Insyma), 84-87. https://doi.org/10.2991/ insyma-18.2018.21

Tamimi, D. K. A. M. A., \& Obeidat, S. F. (2013). Determinants of Capital Adequacy in Commercial Banks of Jordan an Empirical Study. International Journal of Academic Research in Economics and Management Sciences, 2(4), 44-58. https:// doi.org/10.6007/ijarems/v2-i4/53

Tangngisalu, J., Hasanuddin, R., Hala, Y., Nurlina, N., \& Syahrul, S. (2020). Effect of CAR and NPL on ROA: Empirical study in Indonesia Banks. Journal of Asian Finance, Economics and Business, 7(6), 9-18. https://doi.org/10.13106/jafeb.2020.vol7. no6.009

Widarjono, A., Anto, M. B. H., \& Fakhrunnas, F. (2020). Financing Risk in Indonesian Islamic Rural Banks: Do Financing Products Matter? Journal of Asian Finance, Economics and Business, 7(9), 305-314. https://doi.org/10.13106/jafeb.2020. vol7.no9.305

Wong, J., Choi, K.-F., \& Fong, T. P.-W. (2008). Determinants of the Capital Level of Banks in Hong Kong. The Banking Sector in Hong Kong, (September), 159-190. https://doi. org/10.1057/9780230227378_8 